\section{References}

${ }^{1}$ Kirklin JW, Wallace RB, McGoon DC, et al. Early and late results after intracardiac repair of tetralogy of Fallot. Five years' review of 337 patients. Ann Surg $1965 ; 165 \cdot 578-89$.

${ }^{2}$ Gersony WM, Battany S, Bowman FO Jr, et al. Late follow-up of patients evaluated haemodynamically after total correction of tetralogy of Fallot. f Thorac Cardiovasc Surg 1973;66:209-13.

${ }^{3}$ Clayman JA, Ankeney JL, Liebman J. Results of complete repair of tetralogy of Fallot in 156 consecutive patients. Am F Surg 1975;130: 601-5.
${ }^{4}$ Hallidie-Smith KA, Dulake M, Wong M, Oakley CM, Goodwin JF. Ventricular structure and function after radical correction of the tetralogy of Fallot. Br Heart $\mathcal{F} 1967 ; 29: 533-47$.

5 Meyer EC, Tulsky AS, Sigmann P, Silber EN. Pregnancy in the presence of tetralogy of Fallot. Am $\mathcal{F}$ Cardiol $1964 ; 14: 874-9$.

6 James FW, Kaplan S, Chou TC. Unexpected cardiac arrest in patients after surgical correction of tetralogy of Fallot. Circulation 1975;52: 691-5.

(Accepted 4 fune 1982)

\title{
Changes in serum amylase and its isoenzymes after whole body irradiation
}

\author{
A BARRETT, A JACOBS, J KOHN, J RAYMOND, R L POWLES
}

\begin{abstract}
A study was carried out to assess the effect of total body irradiation on pancreatic and parotid isoenzymes of amylase in patients about to undergo bone-marrow transplantation who had received high-dose cyclophosphamide. Twelve patients were studied, enzyme activity being measured before and at various times after total body irradiation. Serum total amylase activity rose rapidly within 12 hours of irradiation to a maximum at 36 hours, returning to normal by six days; most of the increase was derived from salivary damage, with a much smaller pancreatic component.

These results confirm that radiation produces acute changes in amylase activity, which may be of use in assessing radiation-induced damage.
\end{abstract}

\section{Introduction}

The preconditioning regimen for patients undergoing bonemarrow transplantation for acute leukaemia includes high-dose cyclophosphamide $\left(3 \mathrm{~g} / \mathrm{m}^{2} \times 2\right)$ followed by total body irradiation to a dose of about $10 \mathrm{~Gy}$ (1000 rad). A rise in serum amylase activity was noted in these patients, and acute parotitis occurred. We therefore undertook a study to determine the effect of total body irradiation on pancreatic and parotid isoenzymes of amylase.

\section{Patients, methods, and results}

Serum amylase activity was measured in 10 consecutive unselected patients before total body irradiation and daily until it returned to normal using the Phadebas method. ${ }^{1}$ Serum amylase and pancreatic and salivary isoenzyme activities were then measured in a further 12 patients before total body irradiation and at varying times after

Institute of Cancer Research and The Royal Marsden Hospital, Sutton, Surrey

A BARRETT, MB, FRCR, senior lecturer and honorary consultant in radiotherapy

A JACOBS, BSC, MRCP, registrar in haematology (present appointment: fellow, Division of Haematology-Oncology, University of California, Los Angeles, California 90024, USA)

J KOHN, FRCPATH, DCP, consultant clinical pathologist

J RAYMOND, BSC, medical laboratory scientific officer

R L POWLES, MD, FRCP, physician in charge, leukaemia unit treatment using a quantitative inhibition technique, a diagnostic isoamylase test (Pharmacia), ${ }^{2}$ and electrophoretic separation cellulose acetate as reported by Davis. ${ }^{3}$ Control values were obtained in 16

Amylase activity before (pre) and after total body irradiation*

\begin{tabular}{|c|c|c|c|c|}
\hline $\begin{array}{l}\text { Case } \\
\text { No }\end{array}$ & $\begin{array}{c}\text { Time of } \\
\text { measurement } \\
\text { (hours) }\end{array}$ & $\begin{array}{c}\text { Total } \\
\text { amylase } \\
(\mathrm{U}+/ 1)\end{array}$ & $\begin{array}{c}\text { Pancreatic } \\
\text { isoenzyme } \\
(\mathrm{U} / 1)\end{array}$ & $\begin{array}{c}\text { Salivary } \\
\text { isoenzyme } \\
(\mathrm{U} / \mathrm{l})\end{array}$ \\
\hline \multirow{5}{*}{1} & $\begin{array}{l}\text { Pre } \\
24\end{array}$ & $\begin{array}{r}90 \\
2490\end{array}$ & $\begin{array}{r}66 \\
594\end{array}$ & $\begin{array}{r}84 \\
1896\end{array}$ \\
\hline & $\begin{array}{l}48 \\
60\end{array}$ & $\begin{array}{r}1296 \\
918\end{array}$ & $\begin{array}{l}360 \\
270\end{array}$ & 936 \\
\hline & $\begin{array}{l}60 \\
72\end{array}$ & $\begin{array}{l}918 \\
216\end{array}$ & $\begin{array}{r}770 \\
54\end{array}$ & $\begin{array}{l}648 \\
162\end{array}$ \\
\hline & Pre & 78 & 48 & 30 \\
\hline & 12 & 720 & 420 & 300 \\
\hline \multirow[t]{3}{*}{2} & 24 & 1600 & 732 & 870 \\
\hline & $\begin{array}{l}48 \\
72\end{array}$ & $\begin{array}{l}290 \\
432\end{array}$ & $\begin{array}{l}486 \\
180\end{array}$ & $\begin{array}{r}1800 \\
252\end{array}$ \\
\hline & Pre & 36 & 24 & 12 \\
\hline \multirow[t]{2}{*}{3} & 24 & 520 & 180 & 342 \\
\hline & 48 & 660 & 144 & 420 \\
\hline \multirow{4}{*}{4} & Pre & 66 & 42 & 24 \\
\hline & 24 & $\begin{array}{r}2400 \\
2600\end{array}$ & $\begin{array}{l}480 \\
102\end{array}$ & 1920 \\
\hline & $\begin{array}{l}48 \\
72\end{array}$ & $\begin{array}{r}2600 \\
420\end{array}$ & $\begin{array}{l}192 \\
150\end{array}$ & 1440 \\
\hline & Pre & $\begin{array}{l}420 \\
290\end{array}$ & $\begin{array}{r}150 \\
60\end{array}$ & 270 \\
\hline \multirow{5}{*}{5} & 12 & 4800 & $\begin{array}{r}60 \\
1100\end{array}$ & $\begin{array}{r}204 \\
3420\end{array}$ \\
\hline & 36 & 2100 & 414 & 1550 \\
\hline & 48 & 1700 & 470 & 1170 \\
\hline & $\begin{array}{l}60 \\
72\end{array}$ & $\begin{array}{r}1000 \\
800\end{array}$ & $\begin{array}{l}288 \\
48\end{array}$ & $\begin{array}{l}740 \\
792\end{array}$ \\
\hline & Pre & 72 & 36 & $\begin{array}{r}92 \\
36\end{array}$ \\
\hline \multirow{3}{*}{6} & $\begin{array}{l}244 \\
36\end{array}$ & $\begin{array}{l}1530 \\
4000\end{array}$ & $\begin{array}{r}1044 \\
72\end{array}$ & $\begin{array}{r}396 \\
3888\end{array}$ \\
\hline & $\begin{array}{l}30 \\
48\end{array}$ & 4460 & 324 & $\begin{array}{r}5888 \\
4140\end{array}$ \\
\hline & $\begin{array}{l}60 \\
72\end{array}$ & $\begin{array}{l}720 \\
468\end{array}$ & $\begin{array}{l}306 \\
126\end{array}$ & $\begin{array}{l}414 \\
342\end{array}$ \\
\hline \multirow{3}{*}{7} & 12 & 2340 & 522 & 1818 \\
\hline & $\begin{array}{l}244 \\
48\end{array}$ & 2160 & 522 & 1638 \\
\hline & $\begin{array}{l}48 \\
72\end{array}$ & $\begin{array}{l}864 \\
360\end{array}$ & $\begin{array}{r}204 \\
66\end{array}$ & $\begin{array}{l}660 \\
294\end{array}$ \\
\hline \multirow{3}{*}{8} & Pre & 132 & 6 & 126 \\
\hline & 12 & 2340 & 522 & 1818 \\
\hline & $\begin{array}{l}36 \\
60\end{array}$ & $\begin{array}{r}540 \\
78\end{array}$ & $\begin{array}{r}144 \\
12\end{array}$ & $\begin{array}{r}396 \\
66\end{array}$ \\
\hline \multirow{3}{*}{9} & Pre & 132 & 6 & $\begin{array}{r}00 \\
126\end{array}$ \\
\hline & 12 & 2160 & 504 & 1656 \\
\hline & $\begin{array}{l}30 \\
60\end{array}$ & 288 & $\begin{array}{r}48 \\
48\end{array}$ & $\begin{array}{l}828 \\
240\end{array}$ \\
\hline \multirow{4}{*}{10} & Pre & 138 & 42 & 96 \\
\hline & 12 & 810 & 180 & 630 \\
\hline & & 195 & 12 & 183 \\
\hline & $\begin{array}{r}60 \\
108\end{array}$ & $\begin{array}{r}180 \\
90\end{array}$ & $\begin{array}{l}66 \\
36\end{array}$ & $\begin{array}{r}114 \\
54\end{array}$ \\
\hline \multirow{3}{*}{11} & 12 & 9000 & 1200 & 6024 \\
\hline & 24 & $\begin{array}{r}5600 \\
3\end{array}$ & 1000 & 4500 \\
\hline & $\begin{array}{l}48 \\
72\end{array}$ & $\begin{array}{l}3000 \\
1100\end{array}$ & $\begin{array}{r}210 \\
78\end{array}$ & $\begin{array}{r}3000 \\
900\end{array}$ \\
\hline \multirow{3}{*}{12} & Pre & 140 & 120 & 40 \\
\hline & 12 & 2300 & 620 & 1920 \\
\hline & $\begin{array}{l}36 \\
60\end{array}$ & $\begin{array}{l}900 \\
340\end{array}$ & $\begin{array}{l}120 \\
120\end{array}$ & $\begin{array}{r}800 \\
40\end{array}$ \\
\hline
\end{tabular}

*Control values-normal subjects $(\mathrm{n}=16)$ : total amylase $170 \mathrm{U} / 1$, pancreatic isoenzyme $87 \mathrm{U} / 1$, salivary isoenzyme $83 \mathrm{U} / 1$; leukaemic patients $(\mathrm{n}=9)$ : total amylase $178 \mathrm{U} / 1$, pancreatic isoenzyme $80 \mathrm{U} /$, salivary isoenzyme $98 \mathrm{U} / \mathrm{l}$ tOne unit of amylase is the amount of enzyme catalysing the hydrolysis of $1 \mu \mathrm{mol}$
of substrate (glucosidic linkage)/minute at $37^{\circ} \mathrm{C}$ and is equivalent to $60 \mu \mathrm{katals}$. 
normal subjects (laboratory workers) and nine patients with leukaemia who were not undergoing total body irradiation. after chemotherapy to induce remission.

Acute parotitis occurred in most patients within 12 hours after the start of total body irradiation, with considerable swelling and tenderness. This returned to normal within 48 hours, although dryness of the mouth and altered taste persisted for up to six months

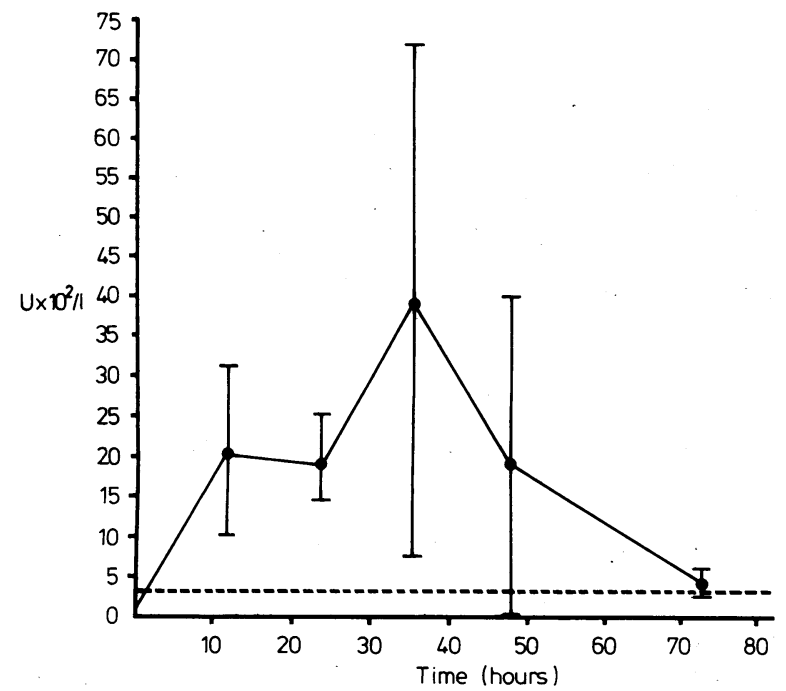

Mean total serum amylase activity after total body irradiation. (Bars indicate SEM; broken horizontal line indicates upper limit of normal.)

after irradiation. Out of 121 patients who underwent bone-marrow transplantation at this hospital, none had clinical signs or symptoms of acute pancreatitis and none developed chronic pancreatitis or evidence of pancreatic insufficiency, the maximum follow-up being three years.

Serum amylase activity rose rapidly within 12 hours of total body irradiation to a maximum at 36 hours, with a rapid return to normal in all cases by six days (figure). Later rises in activity were not observed. All values for the normal and leukaemic controls except one fell within the normal range for our laboratory (70-300 U/1).

Electrophoresis and the quantitative inhibition technique showed that most of the increase in amylase activity was derived from salivary damage, with a much smaller pancreatic component. Quantitation showed that values were usually maximal between 12 and 24 hours, although in half of the patients maximum salivary amylase activity occurred later, at 36 to $\mathbf{4 8}$ hours (table). Pretreatment values were regained within four to six days.

\section{Discussion}

Total body irradiation and cyclophosphamide given before bone-marrow transplantation produce a transient rise in serum amylase activity, which returns to normal by six days. Most of this rise is due to the salivary isoenzyme and is associated with symptoms of acute parotitis. Rises in pancreatic isoenzyme activity occur but are much smaller, and clinical pancreatitis has not been seen in our patients. Measurement of amylase activity may be used as an end point for radiation damage in some animal models. ${ }^{4}$ This study confirms that radiation produces acute changes in amylase activity that may be of use in man in assessing the degree of radiation-induced damage.

Further studies are needed to correlate the dose of irradiation with the amount of parotid damage as shown by a rise in serum amylase activity. This may then prove a useful end point in estimating doses received in radiation accidents.

\section{References}

1 Ceska M, Hultman E, Ingelman B. A new method for determination of alpha-amylase, Experientia 1969;25:555-6.

2 O'Donnell MD, FitzGerald O, McGeeney KF. Differential serum amylase determination by use of an inhibitor, and design of a routine procedure. Clin Chem 1977;23:560-6.

3 Davies TJ. A fast technique for the separation and detection of amylase isoenzymes using a chromogenic substrate. $\mathcal{F}$ Clin Pathol 1972 ;25:266-7.

4 El-Mofty SK, Kahn AJ. Early membrane injury in lethally irradiated salivary gland cells. Int $\mathcal{F}$ Radiat Biol 1981 ;39:53-63.

(Accepted 28 May 1982)

\section{SHORT REPORTS}

\section{Bladder fever: rare complication of the "safe period" method of contraception}

There is an increasing fashion for the use of the so-called "natural" method of contraception which is recommended by its proponents on the basis of its lack of side effects. We draw attention to a potentially serious associated risk that must be anticipated and may be avoided by careful explanation of the method.

\section{Case report}

An 18-year-old girl presented to the casualty department of this hospital stating that she had been practising the natural method of contraception and while attempting to measure her temperature vaginally, had lost her thermometer. During the next five hours she had experienced some dysuria.

Examination showed a healthy young woman with no abdominal signs. Rectal examination was normal and on vaginal examination there was no evidence of vaginal injury, but the thermometer could be palpated anterior to the vaginal wall in the upper third. Plain abdominal radiography confirmed that the thermometer was in the pelvis (figure). We concluded that the thermometer was in the bladder and that she had inadvertently passed it via the urethra.

She was taken to theatre and at cystoscopy the thermometer was visualised lying transversely in the bladder (reading $37^{\circ} \mathrm{C}$ ). Attempts to remove it with biopsy forceps, which had been proved able to grasp a hospital clinical thermometer, failed. After some consideration a lasso was constructed using

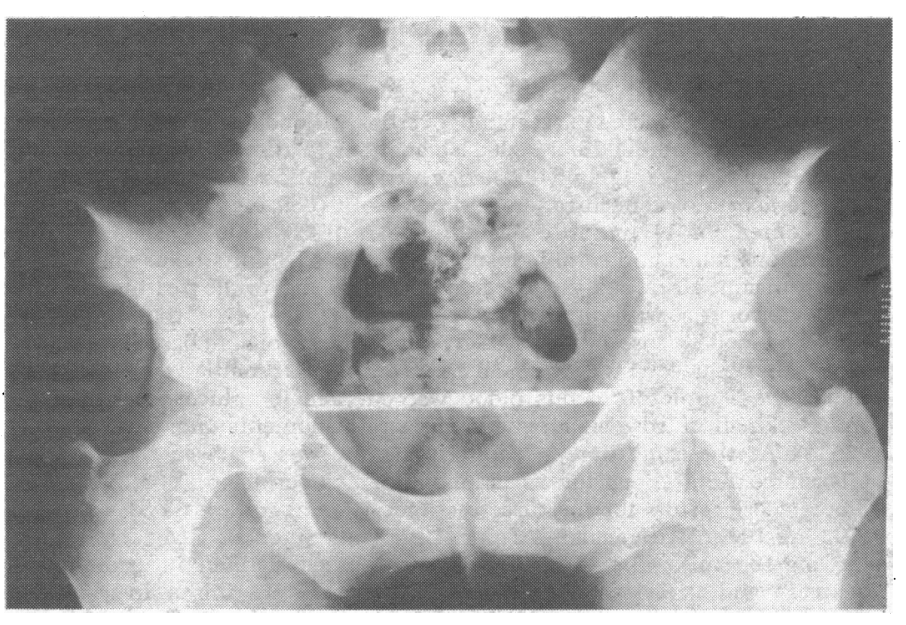

Radiograph showing thermometer in the pelvis. 